lettere for andre omkring ham å forstå hva som foregikk, hvorfor han handlet som han gjorde. Særlig ble det viktig for en kjent person. Boken forteller også hvordan det oppleves å ha en demenssykdom, hvordan det føles å glemme ting, ikke å kunne dra til jobben hver dag. Jan Henry setter klare ord på dette. Laila Lanes beskriver hvordan det oppleves å være pårørende til en som har demens: å bli irritert når vedkommende ikke husker og spør om den samme tingen mange ganger, å føle seg frustrert fordi man ikke kan være hjemme hele dagen.

Men det aller viktigste er det at forfatterne beskriver at livet forsetter som vanlig, at det må fortsette som vanlig. Det beskrives hvor viktig det er å skape gode opplevelser i hverdagen, reise, møte venner som man gjorde før sykdommen satte inn. Og hvor viktig det er at kjærligheten må fortsette å blomstre - og det gjør det for paret Lanes og Olsen. Beskrivelsen av kjærligheten mellom de to er både gripende og rørende. Jegpersonen sier at de på en måte er heldige, fordi de har fătt vite om sykdommen, fordi de nå vet at det haster å ha disse gode opplevelsene, det vil si: å skynde seg å elske.

Maria Lage Barca

Geriatrisk avdeling

Nasjonal kompetansesenter for aldring og helse Oslo universitetssykehus, Ullevål

\section{Uhyggelige historier}

Lunde A.

Noen iblant oss

96 s. Oslo: Aschehoug, 2009. Pris NOK 299 ISBN 978-82-03-19553-2

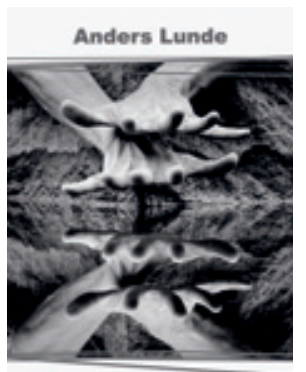

Noen iblant oss
Noen iblant oss er en novellesamling signert debutant Anders Lunde (f. 1976). De ti novellene byr på uhyggelige møter med livets og sinnets mørkere sider Lunde inviterer oss inn $i$ en litterær verden preget av antisosiale person-

ligheter, drapsfantasier og glidende overganger mellom drøm og virkelighet. Fortellerinstansen $\mathrm{i}$ tekstene er tidvis ustabil og upålitelig. Leserens fantasi mobiliseres, og dette bidrar til å vekke ubehagelige følelser. Lunde byr oss brokker av historier, og man blir sittende igjen med et ønske om å vite mer. Hva er bakgrunnen for hendelsene eller hovedpersonens fantasier? Tekstene gir oss sjelden noen bakenforliggende forklaring, og dette er et grep som bidrar til å gi en makaber effekt.
Novellene gir innblikk i virkeligheter og fenomener som ikke er helt fremmed for oss, og som man som lege blir konfrontert med i profesjonelle sammenhenger. Det er tidvis ubehagelig å lese tekstene, og som lege fristes man til å bruke psykiatriske begreper i forståelsen av de tankemønstre og den atferd som Lunde skildrer. Jeg får litterære assosiasjoner til verk av Edgar Allan Poe, Nikolaj Frobenius, Franz Kafka (Metamorfosen) og Charlotte Perkins Gilman (Det gule tapetet). Noen iblant oss er en brutal og sterk novellesamling som kan være nyttig å lese - men som også kan brukes som utgangspunkt for diskusjon i faglige sammenhenger.

Jan C. Frich

Avdeling for helseledelse og helseøkonomi Institutt for helse og samfunn

Universitetet i Oslo

\section{Vakker bok fra en overlevende}

Braadland JF

\section{Bare en overlevende}

Tekst og bilder i et post-tsunamisk perspektiv. 159 s, ill. Oslo: Tekstforlaget, 2009.

Pris NOK 349

ISBN 978-82-992312-3-7

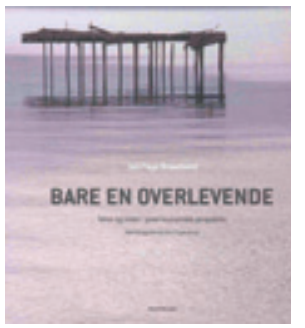

Målet for psykisk traumatiserte er ikke å glemme den overveldende påkjenningen, men å ikke måtte tenke på den. Forfatteren av denne vakre boken deler med leseren gjennom dikt, fotografier og egenberetninger sine opplevelser og minner som tsunamioverlevende. Tittelen «Bare en overlevende» henspiller på at han, fordi han ikke mistet nærstående, følte seg nedprioritert i forhold til overlevende som led tap og andre etterlatte.

I del 1 gir han en medrivende beskrivelse av de øvrige fire aspektene i katastrofepåkjenningen slik den artet seg for mange av de overlevende: dødsfaren, den fysiske skaden, de grufulle vitneopplevelsene og det vanskelige valget mellom egen overlevelse og å redde andre. Å forsøke å gi en sammenhengende beretning, et såkalt narrativ, av en overveldende påkjenning, har gjennom tidene sannsynligvis vært menneskehetens viktigste måte å overkomme traumatiske reaksjoner på. Å fortelle en personlig historie føyer sammen fragmenterte og splittende inntrykk og bidrar til at opplevelsen gjennom gjentakelser blir en erfaring. Dit har forfatteren ennå ikke nådd på det tidspunktet han skrev denne boken. Men skrivingen har sannsynligvis vært til hjelp for ham og kan bli det for andre.

I del 2 illustrerer Braadlands kone, Essi Frydenlund, også en overlevende, med fotografier hans dikteriske gjengivelse av katastrofepåkjenningen og hvordan den i ettertid lever i ham. Det er særlig disse sidene som kan leses med stort utbytte av andre som ble berørt eller rammet av katastrofen, som også gjør den til et supplement til faglitteratur. Bruken av kunst og diktning minner om at det finnes andre kilder til innsikter enn de strengt vitenskapelige.

Braadland gjengir i del 3 noen faktabeskrivelser av tsunamien og av posttraumatiske stressplager. Som enkelte andre tsunamirammede hevder han sterkt kritiske synspunkter på norske myndigheters forsøk på å hjelpe de rammede. I gjengivelsen av forskningsresultater fra forløpsundersøkelser av overlevende og etterlatte ville forfatteren vunnet på å oppdatere seg. Han ville da ha oppdaget at risikoen for psykiske helseskader har vist seg å være langt høyere hos tapsrammede overlevende enn hos dem som «bare» overlevde. Henimot hver annen person som både var i dødsfare og mistet en nærstående, led av en diagnostiserbar psykisk lidelse to år etter tsunamien. Likevel gjør forfatterens subjektivitet, hans åpenhet om hvordan tidligere livsproblemer ble påvirket av tsunamipåkjenningen, hans følsomme registreringsevne og introspektive kapasitet det lett å anbefale denne boken.

Lars Weisæth

Nasjonalt kunnskapssenter om vold og traumatisk stress

Universitetet i Oslo

\section{For mange pasienter og for få pleiere}

Panagiotaki E.

\section{Adjø Felicia}

Hjemmesykepleier i det rike Norge. 215 s.

Oslo: Spartacus forlag, 2009. Pris NOK 299 ISBN 978-82-430-0470-2

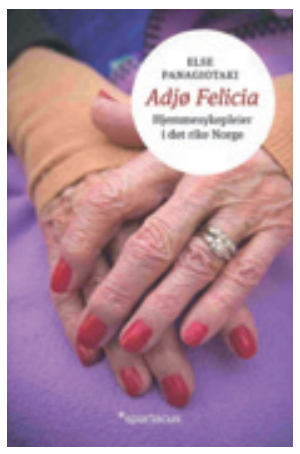

Forfatteren er norsk sykepleier, giftet seg med en greker og har bodd mange år på Kreta. Hun fikk lyst på et år i det gamle landet, som i mellomtiden var blitt rikt. Derfor tok hun seg jobb i hjemmesykepleien $\mathrm{i}$ bydel Frogner i Oslo, den velstående overklassebydelen i det gamle Oslo. Hun forteller om opplevelsene gjen- 